\title{
Use of Job Enrichment Technique and Human Resource Management Performance, Among Extension Managers in North West Province South Africa
}

\author{
Thafe D.R \\ Oladele. 0.1 \\ Department of Agricultural Extension, North West University, South Africa \\ Email: oladele20002001@yahoo.com
}

\section{Doi:10.5901/mjss.2014.v5n15p11}

\begin{abstract}
The study examined knowledge and utilization of job enrichment techniques among extension managers in North West Province. The population of the study area is extension managers in the North West Province of South Africa. Thirty (30) Extension Managers were sampled randomly from the Department of Agriculture and Rural Development database in the four district municipalities of the Province. Data were collected using questionnaires and analysis was done with statistical package for social sciences (SPSS) using frequency counts, percentages and multiple regressions. The findings show that $70 \%$ of extension managers are married and mostly are male (66.7\%), 86.7\% have 1 to 3 children with $63.4 \%$ having $1-3$ dependents; $33.3 \%$ of the respondents were Diploma holders; $30 \%$ were Degree holders, 30\% had Honours, $6.7 \%$ had MSc; $70 \%$ are currently studying for higher degree. The most prominently used information sources were advisory leaflets (100\%), most managers were not knowledgeable on removal of power of a subordinate improve job satisfaction(80); while the most prominent job enriching techniques used by extension managers was adjustment of performance target (80\%). The results further show that there is a significant relationship between the independent variables and the use of job enrichment techniques with $F$ value of $1.83, p<0.05, R=0.717$. The result further predicted 52 percent of the variation in use of job enrichment techniques and human resource management performance by extension managers. The significant determinants of use of job enrichment techniques and human resource management performance among extension managers in North West Province are age $(t=-2.155, p=.046)$, tenure in profession $(t=2.202, p=.042)$ and job designation $(t=-2.273, p=.036)$.
\end{abstract}

\section{Introduction}

South African has long been characterized as having two agricultures. The roots of the "two agricultures" thesis originates in the instruments used by the South African State to support white commercial farmers on the one hand and measures to regulate agricultural production and land-use management in the former reserves and homeland areas on the other during the apartheid era. The history of agricultural extension in South Africa started with the introduction of a variety of measures such as the monopoly of powers, direct controls over imports and exports, and guaranteed prices and guaranteed markets via the Marketing Acts of 1937 and 1968; the 1939 Agricultural Co-operatives Act; the provision of infrastructure such as electricity, roads, railways, telecommunications and irrigation water through other state departments and agencies; financial assistance through the Agricultural Credit Board and the Land Bank, with credit provided at subsidised interest rates and on preferential terms to farmers who could not access credit from the commercial banks (Sustainable Development Consortium, 2007). Given this favourable environment agricultural production in South Africa exceeded both population increase and consumption requirements. It is however unfortunate that in the midst of this plenty a large numbers of black South Africans remained too poor to buy adequate food for their families (Singini \& van Rooyen, 1995). In 1945 Department of Native Affairs published A New Era for Reclamation which set out the vision for betterment land use planning and villagisation, this was followed by Tomlinson Commission which was rejected by the nationalist recommendations for depopulating the reserves and investing in agricultural development.

The homeland era in 1976 opened the way for homeland extension services and the development of agricultural development parastatals. Although it was a ray of hope for the rural areas nevertheless the ratio of extension personnel to black farmers was 1: 600 compared to 1: 30 for white farmers. The parastatal homeland development approach during the 1970s and early 1980's revolved around centrally managed showcase capital intensive projects. The Development Bank of Southern Africa which was established in 1983 introduced the Farmer Support Programme (FSP) as an alternative to the large capital intensive schemes. The FSP focused on small farmers in the homeland areas. It set out to integrate the promotion of agricultural activities with other non-farm related rural development activities (Van Rooyen, 
1995). This was followed by a transition which was an agricultural development programme heralded by the Government of National Unity with focus on Rural Development Strategy which lead to the creation of a national network of local service centres (LSCS) where a variety of agricultural services can be accessed. In 1995 after the eclipse of the rural development strategy, a white paper on agriculture was introduced. This led to a re-engineering of research and extension with a shift from commercial agriculture, to a new focus on "basic research in the context of resource-poor farmers" (Department of Agriculture, 1995). This was to enhance the capacity of small-scale farmers through appropriate support services with the extension agent acting as a facilitator.

The post 1994 period the Department of Agriculture was restructured where provincial Departments of Agriculture were established and due to inability to maintain support services to farmers, most commercial farmers have switched to privately provided services (Vink \& Kirsten, 2003). Duvel, (2003) reported that given the low qualification and competence of extension workers, an extensive and structured support programme should be developed and implemented. The Participatory Programmed Extension Approach (PPEA) was recommended for South Africa consisting of five linked programmes: extension planning and projects, extension linkage and coordination, knowledge and support, education and training, monitoring and evaluation. In 2005 the Department of Agriculture published norms and standards in a bid to: improve access to agriculture support services (information, finance, inputs, regulatory services, technical expertise, markets,) endow farmers with skills and knowledge for ensuring sustainable resource management; facilitate their access to new technologies; enhance communication with farmers and farmer organizations, mentors and advisors (Department of Agriculture, 2005). In 2008 the extension recovery plan was launched in order to ensure accountability and visibility of extension, promote professionalism and improve the image, re-skilling and re orientation of extension, provision of ICT infrastructure and other resources as well as recruitment of personnel. The on-going process of agricultural extension policy formulation will iron out some of the existing deficiencies and reinvigorate the extension workforce. Extension service delivery requires a workforce that is highly motivated for the extension agency to achieve its goal. An organization is as good as its workforce/ employees.

\subsection{Job Enrichment as a Technique for Job Motivation, Satisfaction, and Performance}

Motivation has been defined by many contemporary authors, some of which include; the psychological process that gives behaviour purpose and direction (Kreitner, 1995); a predisposition to behave in a purposive manner to achieve specific unmet needs (Buford, Bedeian and Lindner, 1995); and an internal drive to satisfy an unsatisfied need (Higgins, 1994).

Motivation has been defined in the context of an organization as the inner force that drives individuals to accomplish personal and organizational goals (James, 2008). According to Smith (1994), the need for motivated employee is survival. Motivated employee therefore can be seen as the "lifewire" of its organization. Any organization with a corps of unmotivated employee is a "living death". To be effective as an organization, managers need to understand what motivates employees within the context of the role they perform. The act of motivating employee is very complex which is due, in part, to the fact that what motivates employees changes constantly (Beder, 1990; Watanabe, 1991).

James (2008) reported that interesting work and employees' pay appear to be important links to higher motivation. Options such as job enlargement, job enrichment, promotions, internal and external stipends, monetary and nonmonetary compensation should be considered. He also reported that job enrichment could be used to make work more interesting and increase in pay by adding level of responsibilities to a job and providing monetary compensation to employees for accepting the responsibilities. Herzberg (1966), Leach and Wall (2004), defined job enrichment as a type of job redesign intended to reverse the effects of tasks that are repetitive, requiring little autonomy. Some of these effects are boredom, lack of flexibility, and employee dissatisfaction.

Herzberg argued that job enrichment is required for intrinsic motivation and that it is a continuous management process. Furthermore, by enriching a job, the individual increases his or her job satisfaction and thus, positive motivation. If job enrichment therefore is a key factor to job satisfaction and positive motivation, it is important for extension managers to include job enrichment strategies in their management practices in order to retain a productive workforce. BSCAI, (2005) reported that job enrichment is essentially a structured system of increasing employee responsibility and authority through effective, well-directed delegation. The effectiveness of extension services is dependent upon the motivation of its employee, (Chesney, 1992, Buford, 1990, Smith 1990). In the farmers support services unit for extension services, the status quo remain the same, as there is no funding and facilities to increase the motivation of the extension agents. It is therefore important to look for other means of reinforcing the motivational factors. Motivating employees is always one of every manager's goals. Motivated employees contribute to productivity thus directly increasing profitability for the organization. Structuring jobs and roles correctly is very important in elevating the motivation of employees, which is addressed by job enrichment. Job enrichment therefore, is an important ingredient to reinforce the motivational factors. 
Some of the techniques of job enrichment identified include; removal of control, assignment of complete natural unit of work, re-distribution of power and authority, rotation of jobs, making report directly available and combination of tasks. Although, application of these techniques may take time and effort at the beginning, but like good training, it will pay off with more motivated employees who are willing to work hard and capable of working independently, this means improved motivation and job satisfaction.

\subsection{Objectives of the Study}

The main objective of the study is to determine the knowledge and utilization of job enrichment techniques among extension managers in North West Province. The specific objectives are to: determine the selected personal characteristics, assess the level of knowledge on job enrichment techniques, analyze various job enrichment techniques used by extension managers and their level of use, ascertain the sources of information on job enrichment techniques, and examine constraints facing extension managers in the use of job enrichment techniques. The study also explore significant relationship between the selected personal characteristics, knowledge of job enrichment technique, constraints facing extension managers and the use of job enrichment techniques

\section{Research Methodology}

The study was carried out in the North West Province of South Africa which has an extent of $106512 \mathrm{~km}^{2}$. Its capital is Mahikeng and it is located west of the major population of Gauteng Province with an altitude of 1250 to $1750 \mathrm{~m}$ South of Magaliesberg. Geographically South Africa is located at coordinates $29^{\circ} 00^{\prime}$ South and $24^{\circ} 00^{\prime}$ East, it is ranked $25^{\text {th }}$ in area in the Southern region and its total border area is $4,862 \mathrm{~km}$, most of the province is made of flat areas of scattered trees and grassland. The Magaliesberg mountain range in the northeast extends about $130 \mathrm{~km}$ from Pretoria to Rustenburg. The Vaal River flows along the southern border of the province.In terms of the climate the temperatures range from $17^{\circ} \mathrm{C}$ to $31^{\circ} \mathrm{C}$ in summer and from $3^{\circ} \mathrm{C}$ to $21^{\circ} \mathrm{C}$ in winter. Most of the rainfall falls in summer months of October and April totaling about $360 \mathrm{~mm}$ annually. The main source of income in the North West Province is agriculture. The North West borders the following districts of Botswana; Kgatleng-far northeast, South East-northeast, Southernnorth, Kgalagadi-northwest. Domestically, it borders Limpopo-northeast, Gauteng-east, Free state-southeast and Northern Cape-southwest. Geographically the North West Province is traversed by the north-westerly line of equal latitude and longitude. The North West Province has four district municipalities and twenty local municipalities. The district municipalities are Bojanala Platinum, Ngaka Modiri Molema, Dr Kenneth Kaunda and Dr Ruth Segomotsi Mompati with their local municipalities respectively e.g. Moretele, Mahikeng, Ventersdorp and Greater Taung. The northern and western parts of the province have many sheep farms, cattle and game ranches. The eastern and southern parts are crop growing regions that produce maize, sunflower and citrus fruits. The population of the study area are extension managers in the North West Province of South Africa which is divided into four district municipalities; Bojanala, Ngaka Modiri Molema, Dr Keneth Kaunda,and Segomotsi Ruth Mompati.which are comprised of twenty one (21) local municipalities. Thirty (30) Extension Managers were sampled randomly from the Department of Agriculture and Rural Development data base in the four district municipalities of the North West Province in South Africa. The four district municipalities are Bojanala Platinum, Ngaka Modiri Molema, Dr Kenneth Kaunda and Ruth Segomotsi Mompati. Simple random sample was used of 30 Extension Managers to be interviewed on Use of job enrichment techniques and human resource management performance among Extension Managers in the North West Province South Africa.

The data was collected using questionnaires which included open and closed ended questions. The researcher collected and used both primary and secondary information. The Primary information was collected using structured questionnaires The questionnaires has seven (7) main sections ranging from personal characteristics of respondents, sources of information on job enrichment techniques, knowledge of job enrichment technique, utilization of job enrichment technique, constraints to the use of job enrichment technique, level of human resource management competencies and level of human resource management performance (see annexed questionnaire ' $A$ '). The questionnaire was designed and validated by researchers and the supervisor of University of North West and tested for reliability.Questionnaires were coded, captured and analysis was done using statistical package for social sciences (SPSS) to analyze responses from interviews of extension managers. Quantitative methods where a range of descriptive and inferential statistical procedures with techniques designed in the form of data are used respectively. The regression model was employed to determine the use of job enrichment techniques and human resource management performance among Extension Managers in the North West Province South Africa. 


\section{Results and Discussion}

The personal characteristics of respondents in the study are presented in table 1,70\% of extension managers are married and mostly are male (66.7\%). This shows male dominance in the management level position of the extension profession in terms of gender equity. The majority of the employees (86.7\%) have 1 to 3 children with $63.4 \%$ having 1-3 dependents. This will reduce role conflict between home and office as large family sizes tend to increase role conflicts due to demand on time. The findings from this study showed that 33.3\% of the respondents were Diploma holders; $30 \%$ were Degree holders, 30\% had Honours, $6.7 \%$ had MSc. However, majority of the respondents (70\%) are currently studying for higher degree. This may be due to the introduction of the Extension Recovery plan where funds are provided by government for the training at higher education level. The tenure in profession ranges from 3-20 years with $66.7 \%$ having a tenure of at least 10 years; and $93.3 \%$ at the level of assistant Director. Seventy percent (70\%) of the respondents are studying for higher education as part of upgrading their education level as dictated by the Extension Renewal Plan (DARD, 2005); and most extension managers (63.3\%) reside more than $15 \mathrm{~km}$ from their job location area which poses a problem of travelling costs and extent of accessibility to farmers and thus impact negatively on service delivery. Oladele et al 2010 stated that in Botswana District extension officers, there is also the dominance of males in the extension delivery profession and District extension officers were married. Akinsorotan, et al (2009) reported that that majority of extension managers in south western Nigeria are married, males, with about 39\% having at least BSc as educational qualification. Oladele et al 2010 stated that in Botswana the educational level of many the district extension officers is low but with long years of working experience, between 40 and 50 years of age and had served for more than 20 years. Ogunlade et al (2011) stated that majority of the Zonal Extension Managers in Agricultural Development Projects (ADP) of the northern states in Nigeria were all males with mean age of 49.7 years-old, married and had B.Sc/B.Agric. Mabe and Oladele (2012) found that majority of the extension officers in North West Province, South Africa were male $(76 \%)$ with the mean age of 44.6 years, married and Christians. Forty one percent of the extension officers had Diploma as their educational qualification and a mean of 16.7 years as working experience. Lopokoiyit et al (2012) reported that in Kenya about two-thirds of public and private extension agents attended formal education to improve their education with the majority having trained at the diploma level from certificate level while about one-fifth had undergone training at the degree level from diploma level.

Table 1 : Personal characteristics of respondents

\begin{tabular}{|c|c|c|}
\hline Variables & Frequency & Percentage \\
\hline \multicolumn{3}{|l|}{ Marital status } \\
\hline Single & 1 & 3.3 \\
\hline Married & 21 & 70 \\
\hline Divorced & 4 & 13.3 \\
\hline Widowed & 3 & 10 \\
\hline \multicolumn{3}{|l|}{ Gender } \\
\hline Male & 20 & 66.7 \\
\hline Female & 10 & 33.3 \\
\hline \multicolumn{3}{|l|}{ Number of children } \\
\hline $1-3$ & 26 & 86.7 \\
\hline $4-5$ & 4 & 13.4 \\
\hline \multicolumn{3}{|l|}{ Number of dependants } \\
\hline $1-3$ & 19 & 63.4 \\
\hline $4-5$ & 7 & 23.3 \\
\hline Above 6 & 2 & 6.7 \\
\hline \multicolumn{3}{|l|}{ Educational level } \\
\hline Diploma & 10 & 33.3 \\
\hline Degree & 9 & 30.0 \\
\hline Honors & 9 & 30.0 \\
\hline Mac & 2 & 6.7 \\
\hline \multicolumn{3}{|l|}{ Age } \\
\hline$<40$ years & 8 & 26.7 \\
\hline $40-50$ years & 17 & 56.6 \\
\hline Above 50 & 5 & 16.7 \\
\hline Tenure in profession & & \\
\hline
\end{tabular}




\begin{tabular}{|c|c|c|}
\hline$<5$ years & 8 & 26.7 \\
\hline 6-10 years & 2 & 6.6 \\
\hline 11-15 years & 11 & 36.7 \\
\hline Above 15 years & 9 & 30.0 \\
\hline & & \\
\hline Job designation or rank & & \\
\hline Assistant Director & 28 & 93.3 \\
\hline Acting Assistant Director & 2 & 6.7 \\
\hline Religion & & \\
\hline Traditional & 2 & 6.7 \\
\hline Christian & 28 & 93.3 \\
\hline Ytudying for higher degree & & 70 \\
\hline No & 21 & 30 \\
\hline Living close to job location & 9 & 36.7 \\
\hline Yes & 11 & 63.3 \\
\hline No & 19 & 13.3 \\
\hline Distance in kilometers & & 36.7 \\
\hline$<5 \mathrm{~km}$ & 4 & 10 \\
\hline 6-10 km & 11 & 39.9 \\
\hline 11-15 km & 3 & \\
\hline Above 15 km & 12 & \\
\hline
\end{tabular}

Table 2 presents information sources on job enrichment techniques; the most prominently used information sources were advisory leaflets (100\%), management training and journals at 80 percent each respectively. Oladele et al 2010 stated that prominent sources of information on job enrichment among district extension officers in Botswana are advisory leaflets, journals, workshops, bulletin and workshops and conferences. The use of leaflets (42\%); workshops (43.3\%) and internet (43.3\%) were the least used sources of information among managers. This may be due to the fact that managers were not exploring the use of leaflets and workshops as information sources. Similarly low computer literacy skills, availability and accessibility of information communication technology might be responsible for non-use of internet as source of information on job enrichment technique. Akinsorotan, et al (2009) reported that majority of extension managers in south western indicated the use of workshops, management training and colleagues as information sources. Mabe and Oladele (2012) found that out of the 37 ICT tools listed, extension officers in North West Province, South Africa indicated high level of awareness of nine tools, which include mobile phones, computer, internet, overhead projector, fax machines, organization e mail, fixed telephone, personal email and organization website.

Table 2 : Information sources on job enrichment techniques to Extension Managers

\begin{tabular}{|l|c|c|}
\hline & Yes & No \\
\hline Internet & $24(80)$ & $4(13.3)$ \\
\hline Management training & $24(80)$ & $1(3.3)$ \\
\hline Colleagues & $27(90)$ & $3(10)$ \\
\hline Advisory leaflets & $30(100)$ & $0(0.00)$ \\
\hline Bulletin & $28(93.3)$ & $1(3.3)$ \\
\hline Journals & $24(80)$ & $3(10)$ \\
\hline Workshops & $28(93.3)$ & $2(6.7)$ \\
\hline Seminars/ conferences & $25(83.3)$ & $3(10.0)$ \\
\hline Usage of internet & $13(43.3)$ & $11(36.7)$ \\
\hline Use of management training & $15(50.0)$ & $8(26.7)$ \\
\hline Use of colleagues & $19(63.3)$ & $6(20.0)$ \\
\hline Use of leaflets & $13(42)$ & $12(40.0)$ \\
\hline Use of bulletin & $16(53.3)$ & $4(13.3)$ \\
\hline Journals & $14(46.7)$ & $6(20.0)$ \\
\hline Use of workshops & $13(43.3)$ & $3(10.0)$ \\
\hline conferences/seminars & $14(46.7)$ & $3(10.0)$ \\
\hline
\end{tabular}

Table 3 presents knowledge of job enrichment techniques among extension managers. Knowledge was measured on a 2 point scale of True and false with 33 items. Managers were not knowledgeable on items such as removal of power of a 
subordinate improve job satisfaction(80); provision of additional authority to subordinates will reduce job performance(83.3\%); involvement of subordinates in the identification and solutions of their problems and the organization will increase job dissatisfaction(63.3\%); creation of autonomous work teams with responsibility and authority will reduce confidence(70\%); frequency of removal of control of a subordinate(70\%); assign a complete unit of work that can be done by subordinates without following job procedure (63.3\%). Oladele et al (2010) stated that knowledge of job enrichment techniques was moderate among district extension officers in Botswana and that the use of job enrichment techniques was facilitated by the organization structure for extension delivery in Botswana. The knowledge test has highlighted areas of training needs for the District extension officers. Akinsorotan, et al (2009) reported that in south west Nigeria extension managers are more knowledgeable on techniques such as implementing participative management, increasing direct feedback and rotating assignments among subordinates. Oladele et al (2010) compared the knowledge and utilization of job enrichment techniques among agricultural extension managers in Botswana and Nigeria and reported that extension mangers in the two countries have low knowledge and low utilization of job enrichment techniques. The knowledge test has highlighted areas of training needs for the managers.

Table 3 : Knowledge of job enrichment techniques

\begin{tabular}{|c|c|c|}
\hline Job Enrichment Techniques & False & True \\
\hline Will removal of power of a subordinate improve job satisfaction & $24(80)$ & $6(20)$ \\
\hline $\begin{array}{l}\text { Will assigning a complete unit of work that can be done by subordinate without following job procedure improve } \\
\text { job satisfaction }\end{array}$ & $16(53.3$ & $14(46.6)$ \\
\hline Provision of feedback directly to employees will boast their morale & $5(16.7)$ & $25(83.3)$ \\
\hline Assignment of new or specialized tasks will improve job motivation & $8(26.7)$ & $22(73.3)$ \\
\hline Rotating assignments among subordinates will improve self-confidence on the work & $4(13.3)$ & $26(86.7)$ \\
\hline Implementing participative management will create interesting work environment & $4(13.3)$ & $26(86.7)$ \\
\hline Removal of difficult parts of assignment will reduce workers' productivity & $7(23.3)$ & $23(76.7)$ \\
\hline Increasing performance targets will improve job motivation & $10(33.3$ & $20(66.7)$ \\
\hline Provision of additional authority to subordinates will reduce job performance & $25(83.3$ & $5(16.7)$ \\
\hline Assignments of highly specialized tasks to subordinates will not boost their morale & $16(53.3$ & $14(46.7)$ \\
\hline Reduction of control of a subordinate will improve job satisfaction & $17(56.7$ & $13(43.3)$ \\
\hline Encouraging increased use of skill variety will improve job satisfaction & $14(46.7$ & $16(53.3)$ \\
\hline Increasing the amount of doing a job well will reduce job performance & $17(56.7$ & $13(43.3)$ \\
\hline $\begin{array}{l}\text { Involvement of subordinates in the identification and solutions of their problems and the organization will increase } \\
\text { job dissatisfaction }\end{array}$ & $19(63.3$ & $11(36.7)$ \\
\hline $\begin{array}{l}\text { Provision of subordinates with the feeling that they are personally contributing to the organization will improve job } \\
\text { performance }\end{array}$ & $8(26.7)$ & $22(73.3)$ \\
\hline Combination of various work activities to provide a challenging work assignment will provide job performance & $7(23.3)$ & $23(76.6)$ \\
\hline Increasing direct feedback to employees that involve them will improve job motivation & $8(26.7)$ & $22(73.3)$ \\
\hline Creation of autonomous work teams with responsibility and authority will reduce confidence & $21(70.0$ & $9(30.0)$ \\
\hline Frequency of use of removal of control of a subordinate & $21(70)$ & $9(30)$ \\
\hline Assign a complete unit of work that can be done by subordinates without following job procedure & $19(63.3$ & $11(36.7)$ \\
\hline Provision of feedback directly to employees by supervisor & $9(30)$ & 18(60) \\
\hline Assignment of new or specialized tasks & $7(23.3)$ & $21(70)$ \\
\hline Rotating assignments or job schedules & $10(33.3$ & $18(60)$ \\
\hline Implementing participative management & $7(23.3)$ & $20(66.7)$ \\
\hline Removal of difficult sections of assignments & 15(50) & $12(40)$ \\
\hline Adjusting performance targets & $4(13.3)$ & $23(76.7)$ \\
\hline Reduction of control of a subordinate & $8(26.7)$ & $21(70)$ \\
\hline Provision of additional authority to subordinates & $4(13.3)$ & $25(83.3)$ \\
\hline Increase the degree of decision making for subordinates & $2(6.7)$ & $26(86.6)$ \\
\hline Encouraging increased use of initiatives & $7(23.3)$ & $21(70)$ \\
\hline Increasing the amount of recognition for a job well done & $1(3.3)$ & $25(83.3)$ \\
\hline Involvement of subordinates in the identification and solution of problems that affect them and the organization & $6(20)$ & $21(70)$ \\
\hline Provision of employees with a feeling of belongingness & $3(10)$ & $23(76.6)$ \\
\hline
\end{tabular}

Table 4 presents the results on the utilization of job enrichment techniques by Extension Managers. The most prominent techniques used by extension managers were Adjust performance target (80\%); Increases degree of decision making for 
subordinates (97\%); recognizing the amount of a work well done (90\%) and Employees are provided with a feeling of belongingness (90\%). Akinsorotan, et al (2009) reported that in south west Nigeria the most used job enrichment techniques by extension managers are: increased use of initiatives, increasing the amount of job recognition for job well done and involvement of subordinates in identification and solution of problems.

Table 4 : Utilization of job enrichment techniques by Extension Managers.

\begin{tabular}{|l|c|c|}
\hline \multicolumn{1}{|c|}{ Job Enrichment Techniques } & Yes & No \\
\hline Removal of control of subordinates & $20(67)$ & $10(33)$ \\
\hline Assign a complete unit of work that can be done by subordinates without following job procedure & $19(63)$ & $11(37)$ \\
\hline Provision of feedback directly to employees by supervisor & $23(77)$ & $7(23)$ \\
\hline Rotating assignments or job schedules & $15(50)$ & $15(50)$ \\
\hline Implementing participative management & $12(40)$ & $18(60)$ \\
\hline Removes difficult sections of the assignments & $20(67)$ & $10(33)$ \\
\hline Adjust performance target & $24(80)$ & $6(20)$ \\
\hline Reduction of control of a subordinate & $11(37)$ & $19(63)$ \\
\hline Provide additional authority to subordinates & $1(3)$ & $29(97)$ \\
\hline Increases degree of decision making for subordinates & $29(97)$ & $1(3)$ \\
\hline Encouraging increased use of initiative & $6(20)$ & $24(80)$ \\
\hline Recognizing the amount of a work well done & $27(90)$ & $3(10)$ \\
\hline Involving subordinates in the solution and problems affecting them and the organization & $23(77)$ & $7(23)$ \\
\hline Employees are provided with a feeling of belongingness & $27(90)$ & $3(10)$ \\
\hline Combination and/or arrangement of task to be more challenging & $20(67)$ & $10(33)$ \\
\hline
\end{tabular}

Table 5 presents human resource management competencies of extension managers in the North West Province of South Africa. This was rated on a five point Likert-type scale: 1=very low (VL), 2=low $(L), 3=a v e r a g e ~(A), 4=h i g h(H)$ and $5=$ very high $(\mathrm{VH})$. The most prominent item for which extension managers indicated a high competence is kknowledge of organization (73.3\%). Extension managers ranked themselves as average in 10 out of 11 competencies. This may be due to the low educational level among managers and lack of specialized management training among them. Ogunlade et al (2011) reported that the perceptions of Zonal Extension Managers (ZEMs) in Agricultural Development Projects (ADP) of the northern states in Nigeria regarding their human resource management competence and performance of human resources management activities showed that the highest human resource management competencies perceived by the Zonal Extension Managers were knowledge of organization, interpersonal relations and engagement.

Table 5 : Managers' competencies on human resource management

\begin{tabular}{|l|c|c|c|c|c|}
\hline \multicolumn{1}{|c|}{ Human Resource Management Competencies } & Very low & Low & Average & High & Very high \\
\hline Knowledge of organization & $1(3.3)$ & $2(6.7)$ & $5(16.7)$ & $12(40)$ & $10(33.3)$ \\
\hline Interpersonal relations & $1(3.3)$ & $2(6.7)$ & $15(50)$ & $10(33.3)$ & $1(3.3)$ \\
\hline Engagement & $1(3.3)$ & $1(3.3)$ & $20(66.7)$ & $6(20)$ & $0(0)$ \\
\hline Leadership & $1(3.3)$ & $2(6.7)$ & $21(70)$ & $6(20)$ & $0(0)$ \\
\hline Subject matter & $1(3.3)$ & $3(10)$ & $18(60)$ & $8(26.7)$ & $0(0)$ \\
\hline Community and social processes & $1(3.3)$ & $2(6.7)$ & $24(80)$ & $2(6.7)$ & $0(0)$ \\
\hline Professionalism & $1(3.3)$ & $7(23.3)$ & $14(46.7)$ & $8(26.7)$ & $0(0)$ \\
\hline Educational Programming & $1(3.3)$ & $7(23.3)$ & $9(30)$ & $13(43.3)$ & $0(0)$ \\
\hline Information and education delivery & $1(3.3)$ & $7(23.3)$ & $14(46.7)$ & $8(26.7)$ & $0(0)$ \\
\hline Organizational management & $2(6.7)$ & $7(23.3)$ & $14(46.7)$ & $6(20)$ & $0(0)$ \\
\hline Diversity/Plural/Multiculturalism & $1(3.3)$ & $10(33.3)$ & $12(40)$ & $7(23.3)$ & $0(0)$ \\
\hline
\end{tabular}

Table 6 indicates the level of human resource management performance among extension managers in the North West Province of South Africa. The ability of the zonal managers to perform each of the following human resource management activity was anchored on a four point Likert-type scale: 1=low (L), 2=marginal (M), 3=good and 4=excellent (E). From the 17 listed human resource management activities, extension managers had high proportion under marginal for 10 items. The items for which extension managers indicated good were The ability to understand the history, philosophy and contemporary nature of extension (63.3\%); understand and facilitate opportunities (60\%); The ability to 
broker the necessary resources that best respond to the needs of individuals and communities (76.7\%); Ability to guide behavior change among extension learners (66.7\%); The mastery of communication skill (70\%); Ability to establish structure, organize processes, develop and monitor resources (73\%) and awareness, commitment and ability to include one's own and others' different cultural perceptions, assumptions, norms, believes and values in managing human resources (63.3\%). The human resource management activities for which the Zonal Extension Managers in Agricultural Development Projects (ADP) of the northern states in Nigeria indicated highest means were ability to understand the history, philosophy and contemporary nature of extension and technical proficiency that enhances individual and organizational effectiveness (Ogunlade et al 2011).

Table 6 : Managers' performance on human resource management activities

\begin{tabular}{|c|c|c|c|c|}
\hline Human resources management activities & Low & Marginal & Good & Excelle \\
\hline The ability to understand the history, philosophy and contemporary nature of extension & 2(6.7) & $8(26.7)$ & $16(53.3)$ & $3(10)$ \\
\hline Technical proficiency that enhances individual and organizational effectiveness & $1(3.3)$ & $12(40)$ & $11(36.7)$ & $5(16.7)$ \\
\hline $\begin{array}{l}\text { Ability to interact with diverse individuals and groups to create partnership, networks and dynamic } \\
\text { human systems }\end{array}$ & 1(3.3) & 11(36.7) & 13(43.3) & (13.3) \\
\hline Ability to identify and monitor variables and issues important to community vitality & 1(3.3) & 13(43.3) & $12(40)$ & $4(13.3)$ \\
\hline Ability to influence a diverse indivi & $1(3.3)$ & 14(46.7) & 9(30) & $4(13.3)$ \\
\hline this varia & 1(3.3) & $18(60)$ & $7(23.3)$ & $4(13.3)$ \\
\hline cor rese & $6(20)$ & 11(36.7) & $9(30)$ & $3(10)$ \\
\hline Jnders & $4(13.3)$ & $8(26.7)$ & $15(50)$ & $3(10)$ \\
\hline s. & 3( & $3(10)$ & (26.7) & 15( \\
\hline tencion larnerc & 1(3.3) & $7(23.3)$ & $15(50)$ & $5(16.7)$ \\
\hline The $n$ & 2(6.7) & $6(20)$ & $16(53.3)$ & $5(16.7)$ \\
\hline Ability to establish structure, or & 2(6.7) & $4(13.3)$ & $19(63.3)$ & $3(10)$ \\
\hline $\begin{array}{l}\text { Awareness, commitment and ability to include on } \\
\text { assumptions, norms, believes and values in mana }\end{array}$ & 2(6.7) & $7(23.3)$ & 1(50) & $4(13$ \\
\hline The application & $1(3.3)$ & 1(36.7) & 12(40) & $5(16.7)$ \\
\hline Ability to dem & $3(10)$ & $8(26.7)$ & $12(40)$ & $5(16.7)$ \\
\hline $\begin{array}{l}\text { Ability to plan, design, implement, ev } \\
\text { program that improve quality of life fo }\end{array}$ & $2(6.7)$ & $8(26.7)$ & 10) & )) \\
\hline Ability to lead change to obtain educational outcomes effectively and efficiently & (3.0) & $12(40)$ & $9(30)$ & $6(20)$ \\
\hline
\end{tabular}

The results of the regression model on the analysis of use of job enrichment techniques and human resource management performance among extension managers in North West Province South Africa are presented in table 7 below. The analysis of results shows that there is a significant relationship between the independent variables and the use of job enrichment techniques with $F$ value of $1.83, p<0.05$. Also, $R$ value of 0.717 showed that there was a strong correlation between independent variables and use of job enrichment techniques and human resource management performance among extension managers. The result further predicted 52 percent of the variation in use of job enrichment techniques and human resource management performance by extension managers. The significant determinants of use of job enrichment techniques and human resource management performance among extension managers in North West Province are age $(t=-2.155, p=.046)$, tenure in profession $(t=2.202, p=.042)$ and job designation $(t=-2.273, p=$ .036). Oladele et al (2010) stated that important predictors of job enrichment utilization are information sources on job enrichment, educational level, age and years of experience in Botswana. 
Table 7 : Multiple regression analysis of relationship between socio-economic characteristics and use of job enrichment techniques

\begin{tabular}{|l|c|c|c|c|c|}
\hline \multicolumn{1}{|c|}{ Parameters } & B & Std. error & Beta & t & Sig \\
\hline Marital status & 3.590 & 4.483 & .0207 & 2.801 & .434 \\
\hline Gender & 4.290 & 7.698 & .145 & .557 & .585 \\
\hline Number of children & 1.787 & 4.198 & .119 & .426 & .676 \\
\hline Number of defendants & -0.590 & 1.408 & -.100 & -.419 & .680 \\
\hline Level of education & -4.216 & 3.995 & -.286 & -1.055 & .306 \\
\hline Age & -1.426 & .662 & -.576 & -2.155 & .046 \\
\hline Tenure in Profession & .918 & .417 & .513 & 2.202 & .042 \\
\hline Job Designation/Rank & -24.491 & 10.775 & -.553 & -2.273 & .036 \\
\hline Religion & 2.418 & 11.671 & .043 & .207 & .838 \\
\hline Studying for a higher degree & -.688 & 6.127 & -.023 & -.112 & .912 \\
\hline Living in job location area & -3.325 & 4.259 & -0.184 & -.781 & .446 \\
\hline Distance covered to reach clients & -.153 & .156 & -.261 & -.979 & .341 \\
\hline F & 1.803 & & & & \\
\hline Sig & .022 & & & & \\
\hline R & .717 & & & & \\
\hline R Square & .515 & & & & \\
\hline
\end{tabular}

\section{Conclusion}

This study examined the use of job enrichment techniques and human resource management performance among extension managers in the North West Province. In terms of personal characteristics of extension managers, there is male dominance in the extension profession, a balance of education level exist which is an indication that the Extension Recovery Plan (ERP) has contributed tremendously towards the education level upgrading. The majority of extension managers are aged 40-50 years and above. Their tenure in profession is 5-15years. Most extension managers reside far from their job location areas which is more than $15 \mathrm{~km}$, this affects their performance and productivity. Information sources most prominently used is advisory leaflets and the least used are management training and journals. The respondents reflect that most extension managers have an average knowledge on job enrichment. There is absolutely no frequent use of job enrichment techniques but only rare use thereof, and the level of human resource management competencies and performance is good on average.

\section{References}

Akinsorotan, A. O.; O. I. Oladele, and A. A. Ajadi (2009) Knowledge and Utilisation of Job Enrichment Techniques among Extension Managers in South Western Nigeria; Journal of Extension Systems. Volume 25: 77-89.

Beder, H. (1990). "Reasons for Nonparticipation in Adult Education". Adult Education Quarterly Vol 40. pp 207 - 218.

BSCAI Services Magazines (2005). "Using Job Enrichment to Motivate Employees". In Motivation and Training. Building Services Management Program. Vol.3. pp. 10-12.

Buford, J. A. Jr. (1990). "Extension Management in the Information Age". Journal of Extension. Vol. 28, No 1. http://www.joe.org /joe/1990spring/ent.html\#fut2.Accessed in May, 2008.

Buford, J. A. Jr., A. G. Bedeian and J. R. Lindner, (1995). "Management in Extension" (3rd ed). Columbus, Ohio. Ohio State University Extension.

Chesney,C. E. (1992). "Workforce 2000: Is Extension Agriculture ready?" Journal of Extension Vol. 30 , No 2. http://www.joe.org/joe/1992summer/fut2.html.Accessed in May,2008.

Department of Agriculture. (2005a). National Education and Training Strategy for Agriculture and Rural Development in South Africa.

Department of Agriculture. (2005b). Norms and standards for extension and advisory services in agriculture.

Department of Agriculture. (2008). The state of extension and advisory service within the agricultural Public Service: A need for recovery.

Drago, R., M. Wooden (1992). "The Determinants of Labour Absence: Economic Factors and Workgroup Norms Across Countries". Industrial and Labour Relations Review. Vol. 45, pp135-141.

Fabusoro, E., J. A. Awotunde, C. I, Sodiya, C. I. Alarima (2008). "Status of Job Motivation and Job Performance of Field Level Extension Agents in Ogun State: Implications for Agricultural Development". The Journal of Agricultural Education and Extension. Vol. 14. No. 2 pp 139-152.

Herzerg, F. (1966). "Work and Nature of Work". Cleveland: World Publishing.

Higgins, J. M. (1994). "The Management Challenge"(2nd ed.) New York: Macmillan. 
Hoppcock, R. H. (1935). "Job Satisfaction" (1st ed.). New York: Harper \& Brothers.

James R.M. (2008) "Work System Design to Improve Economic Performance of the Firm". Business Process Management Journal 14(3): $432-446$

Kreitner, R. (1995). "Management" (6 $6^{\text {th }}$ ed). Boston: Houghton Mifflm Company.

Lopokoiyit M. C., C Onyango, J. K. Kibett, B.K. Langat 2012 Human Resource Development in Agriculture Extension and Advisory Services in Kenya in The proceedings of 8th AFMA Congress "Repositioning African Agriculture by Enhancing Productivity, Market Access, Policy Dialogue and Adapting to Climate Change" held at the Sarova Panafric Hotel, Nairobi, 25-29th November . pp 371-388.

Mabe LK and Oladele Ol. Awareness level of use of Information Communication Technologies tools among Extension officers in the North- West Province, South Africa. Life Sci J 2012;9(3):440-444]

Mc.Caslin, N. L. \& J. Mwangi (1994). "Job Satisfaction of Kenya's Rift Valley Extension Agents". Journal of Extension, Vol. 32 No 3. http://www.joe.org/joe/1994october/rbl.html. Accessed in January 2009.

Murphy, K. R. and J. N. Cleveland (1995). "Understanding Performance Appraisal". Thousand Oaks: Sage Publication.

Ogunlade I. , O. Idowu Oladele and F. I. Agboga 2011 Self-perceived competencies assessment and human resource performance of zonal extension managers in northern Nigeria Journal of Food, Agriculture \& Environment Vol.9 (3\&4): 1040 - 1044 .

Oladele O. I (2007). "Influence of Personal Characteristics on Job Performance Among Extension Agents and Agricultural Researchers in South Western Nigeria". Agricultural and Food Science Journal of Ghana Vol. 6 pp 431-444.

Oladele O. I., S. K. Subair and N. V. Sebina (2010)Knowledge and utilization of job enrichment techniques among district agricultural officers in Botswana. African Journal of Agricultural Research Vol. 5(21), pp. 2918-2924, 4 November, 2010

Oladele O. I.; A. O. Akinsorotan and A. A. Ajadi 2010 Knowledge and utilization of job enrichment techniques among agricultural extension managers in Botswana and Nigeria. The Journal of International Social Research Uluslararası Sosyal Ara_tırmalar Dergisi Volume: 3 Issue: 12 Summer 2010 327- 334

Riggs, K. and K. Bues (1993). "Job Satisfaction in Extension". Journal of Extension, Vol. $31 . \quad$ No. 2. http://www.joe.org/joe/1993summer/a5.html.Accessed in February, 2009.

Scott, M. (2004). "Mississippi State University Extension Service Agent's Perceptions of Fundamental Job Characteristics and their Level of Satisfaction". Unpublished master's thesis, Mississippi State University, Mississippi State, Mississippi.

Shaw, J. D., J.E. Delery and M. H Abdulla.( 2003). "Organisational Commitment and

Smith G. P. (1994). "Motivation" in W. Tracey (Ed), Journal of Extension. Vol 28. No 1.

Watanabe, S. (1991), "The Japanese Quality Control Circle: Why it Works". International Labour Review. Vol. 130, No 1. pp 57-59.

Watanabe, S. (1991). "The Japanese Quality Control Circle: Why it Works". International Labour Review. Vol. 130, No 1, pp 57-59.

Wright, M. P. (1995). "Cognitive Ability as a Moderator of the Relationship between Personality and Job Performance." Journal of Management Vol 2, No. 6, pp 1129-1139. 